\title{
Időszemlélet és politikatudomány II. \\ Politikatudományi paradigmák az átmenet utáni Magyarországon
}

\author{
CSIZMADIA ERVIN ${ }^{1}$
}

\begin{abstract}
ABSZTRAKT
Két részes cikksorozata második részében a szerző a rendszerváltás utáni hazai politikatudomány idôszemléletét vizsgálja. Első cikkében megállapította, hogy a nyugati politikatudomány jellemzője volt az elmúlt 60 évben egyfajta „időszemléleti váltógazdálkodás”, azaz a diszciplína képviselöi hol a történelmet részesítették elönyben a jelennel szemben, hol a jelent a történelemmel szemben. Az e tanulmányban vizsgált magyar példában nem beszélhetünk váltógazdálkodásról: az elmúlt 30 évben folyamatosan egy jelen-centrikus szemléletmód van jelen, amely a tranzitológiai paradigmát és annak leágazásait fogalja magában. A tanulmány a Fidesz példáján keresztül mutatja be, hogy a mainstream politikatudomány a Fidesz változásait szinte kizárólag csak ebból a perspektívából értékeli, és e miatt keveset tud mondani a Fidesz (és tágabban a magyar demokrácia) elmúlt korszaka változásainak mélyebb, történeti körülményekkel is összefüggő okairól. A szerző önmagát egyértelmúen a történeti szemléletmód képviselőjének tekinti és ebből a nézôpontból az elmúlt negyedszázad időszemléleti horizontjának felülvizsgálatát szorgalmazza.
\end{abstract}

KULCSSZAVAK: Tranzitológia - Konszolidológia - Magyar politikatudomány - A pártrendszer változása - Paradigmák

\section{ABSTRACT}

\section{Perception of time and politicalscience II. Politicalscienceparadigmsinthe post regimechange Hungary}

In the second part of his two piecees say the author examines the perception of time in Hungarian political science after the change of regime. In his first article, the author stated that for the past 60 years Western political science was characterised by a sort of „rotation” concerning the perception of time, that is, at times the representatives of the discipline favored history over the present, while at other times the present over history. In the case of the Hungarian example examined in this essay, we can not talk of rotation: the past 30 years has constantly favored a present-centricperspective, which embodies the transitology paradigm and its derivatives.

${ }^{1}$ MTA Politikatudományi Intézet (Senior researcher, HAS Centre for Social Sciences Institute for Political Science), tudományos főmunkatárs. 


\section{KÖZELKÉP - Tanulmányok}

The studys hows through the example of Fidesz that mainstream political science is almost exclusively interested in the changes of Fidesz from this perspective, as a result it has very little to say about the deeper causes of the transformations of Fidesz (and Hungarian democracy) during this period of time which are also related to historical circumstances. The author holds himself to be a representative of the historical perspective and urges there-examination of the time perspective of the past quarter of a century through this perspective.

KEYWORDS: Transitology, Consolidology, Hungarianpoltiical Science, Transformation of partysystem, Paradigms

\section{Bevezetés}

A Metszetek 2018. évi 2. számában az olvasó találkozhatott Időszemlélet és politikatudomány. Váltógazdálkodási ciklusok a jelen-centrikus és a történelmi szemléletmód között című tanulmányommal. Az a dolgozat két részes írásom első része volt, s a nyugat-európai politikatudomány elmúlt hatvan évét vizsgálta. Azt a tételt állítottam fel, hogy amikor szakmánkat elemezzük, célszerű figyelnünk a politikatudós-közösség belső szerkezetére, illetve egy eléggé elhanyagolt területre, a tudósok idő-szemléletére. Arra jutottam, hogy egyfajta váltógazdaság figyelhető meg két politikatudományi szemléletmód, a történelmi és a jelen-centrikus között. Az 1960-as években a történelmi látásmód erős a politikatudományban, hogy az 1980-as évek végére ez háttérbe szoruljon, s helyét átvegye a jelen-centrikus szemléletmód, amelyet írásomban a tranzitológiával azonosítok. A 2000-es évektől viszont ismét megerősödik a történelmi látásmód, amely az új historicizmusban, illetve az amerikai politikai fejlődés iskolájában ölt testet.

A fenti dolgozatban jeleztem, hogy a munka egy két részes tanulmány első része (s egyébként a kettő együtt A magyar politikai fejlődés logikája címü könyvem első fejezetének részlete). ${ }^{2}$ Tanulmányom mostani, második része feltételezi az első rész ismeretét, de akár önállóan is olvasható. A dolgozatban kifejezetten magyar terepen vizsgálódom, s azt vizsgálom, a magyar politikatudományban miképpen tükröződnek a nyugat-európai trendek, és nálunk is megfigyelhető-e az említett „időszemléleti váltógazdálkodás”, illetve a rendszerváltás utáni Magyarországon milyen speciális sajátosságok érvényesülnek.

Előzetesen azt kell megállapítanom, hogy (ellentétben az első részben bemutatott nyugat-európai paradigmákkal) a hazai politikatudományon belül nemigen lehetséges elkülöníteni a jelen-centrikus és a történeti paradigmát, ami abból adódik, hogy nálunk a történeti látásmód csak nyomokban érvényesül(t) és paradigmává végképp nem áll(t) össze. Így a történelmi és a jelen-centrikus szemléletmód egymáshoz való viszonyát nem tudom rekonstruálni úgy, mint ahogy ezt a nyugati példán tettem.

${ }^{2}$ Lásd: Csizmadia 2017. 


\section{KÖZELKÉP - Tanulmányok}

Önmagában is elgondolkodtató, hogy ez miért alakult így, de ennek részletezésébe itt nem megyek bele. Annál érdekesebb viszont az általam jelen-centrikusnak nevezett tranzitológiai szemléletmód, illetve az abból kifejlődő „származékos” elméletek (Csizmadia 2016) vizsgálata.

\section{A tranzitológia és konszolidológia Magyarországon}

Magyarországon az átmenet időszakában (1987-90) a tranzitológiai irányzat „jobbnak”, „hatékonyabbnak” és „magyarázóbbnak” tûnt, mint egyébként is bizonytalan kontúrú előd-elmélete, a politikai fejlődés. ${ }^{3}$ A nyugati típusú tranzitológiának azért is volt könnyű gyökeret vernie, mert ehhez nem kellett - Nyugat-Európával szemben - nagyobb szemléletváltás, hiszen itt a 70-es évektől lényegében pragmatikus, gyakorlatias és jelen-centrikus ideológiák formálódtak, s a történelmi szemlélet nem tett szert mélyebb gyökerekre a politikatudományon belül, a mellett, hogy paradigmák általában sem formálódtak ki. Így a magyar tranzitológia - időszemléletét, elemzési perspektíváját illetően - nem áll olyan erősen szemben elődjével, mint ahogyan a nyugati tranzitológia állt szemben a politikai fejlődéssel. A nyugati példában láthattuk, hogy a strukturalista típusú vagy más kifejezéssel: prekondicionista megközelítéseket hogyan szorítja vissza az aktorok cselekvésére fókuszáló és a demokráciák fejlődését illetően univerzalista megközelítés. ${ }^{4}$

A tranzitológia lett tehát a magyar politikatudomány első igazán egységesítő irányzata. Ha közelebb lépünk magyar szerzők szövegeihez, azért találunk egyértelmű jeleket, amelyek arra utalnak, hogy a magyar mainstream elmélet a történelmi szemlélettel szemben kívánja meghatározni magát. Hadd hozzak erre három - időben egymástól részben távol eső - példát. Az első példa G. Márkus György tanulmányából való. A szerző a rendszerváltás utáni törésvonalak, illetve a pártrendszer befagyásáról írva állapítja meg: ez a folyamat egyáltalán nem úgy zajlik, ahogy a 60-as, 70-es években írt klasszikusaiban azt Stein Rokkan megfogalmazta. „A politikai szociológia S. Rokkan által képviselt historicista felfogása ugyanis erősen determinista, amennyiben hosszútávon érvényesülő meghatározottságot tételez." (G. Márkus 1997: 44) Ezzel szemben - folytatja - nem arról van szó, hogy a pártok egyszerűen „törésvonal-fordítók”, hanem maguk alakítják a politikai teret (uo.).

Ugyanebben az évben írott tanulmányának mindjárt első mondataiban hasonlóan foglal állást Husz Dóra is, aki azt írja: „Az 1970-es és az 1980-as években a demokratikus átmeneteket tanulmányozó társadalomtudományi kutatásokban a

\footnotetext{
${ }^{3}$ A politikai fejlődés paradigmájáról tanulmányom 1. részében részletesen szó volt. A „jobbnak”, „hatékonyabbnak”, „magyarázóbbnak” szófordulatokkal visszautalok az ugyancsak az 1. részben tárgyalt Thomas Kuhnra, aki szerint mindig vannak olyan elméletek, amelyek jobbnak tűnnek ellenfeleiknél. Ez nem azt jelenti, hogy igazabbak is, csak azt, hogy „jobbak”, mert a maguk korában több tudós követi őket.

${ }^{4}$ Lásd a tanulmány első részének ide vonatkozó fejtegetéseit: Csizmadia 2018.
} 


\section{KÖZELKÉP - Tanulmányok}

strukturalista megközelítést (lásd Lipset 1959) egyre inkább felváltotta az interakcionizmus. Az interakcionista társadalomtudósok vizsgálatának középpontjában nem a strukturális előfeltételek, hanem a cselekvőképes aktorok állnak. Az interakcionista kutatók szerint az aktorok közötti stratégiai interakció jelentős mértékben befolyásolja az átmenet végeredményét." (Husz 1997: 71)5 Harmadikként pedig beidézném Róna Dániel véleményét, aki hosszan értékeli Lipset és Rokkan híres mûvét (Lipset - Rokkan 1967), s megállapítja: „a mű legalapvetőbb logikai feltevése az, hogy a történelem határozza meg a törésvonalakat, amelyek alakítják a pártrendszert és a szavazói magatartást" (Róna 2008: 125 - kiemelés az eredetiben). Majd utána elemzi a Lipset-Rokkan-tétel revíziójára irányuló későbbi elméleteket, amelyeknek lényege, hogy már nincsenek beszorulva a történelem „fogságába”. ${ }^{6}$

Annyit máris megállapíthatunk, hogy a magyar tranzitológia kiindulópontjánál a történelmi magyarázatokat illető kétely áll, s ezért a hazai teoretikusok nem is alkalmaznak ilyen jellegú magyarázatokat, s - hogy úgy mondjam - „természetes módon” lesznek antihistoricisták és antistrukturalisták.

A „történelem-ellenes” álláspont mainstreammé válásához kellő inspirációt ad továbbá Francis Fukuyamának $A$ történelem vége? című esszéje. Ebben nagyon pregnáns mondatok találhatók, nem csak a történelem, hanem a politika végéről is. Voltaképpen az 1990-től napjainkig tartó időszak mintha nem szólna másról, mint az ebben az írásban megjövendölt politika-képnek a valóra válásáról. ${ }^{7}$ Fukuyama műve hihetetlenül sokfelé ágazik; a történelem és a politika végén túl megjelenik benne az a gondolat is, hogy mostantól a liberális világforradalom határozza meg a további fejlődést. De a másik két alapgondolathoz képest ennek a nagy ívű gondolatnak a rendszerváltás hajnalán még nincs komolyabb recepciója Magyarországon. A tranzitológia nagy része a korai szakaszban - ahogy bemutattam - Nyugat-Európában nemzetállam-központú és ehhez egy hagyományosabb demokrácia-felfogás társul. Fukuyama cikkének megjelenésekor az intézményesedésének magasabb stádiumába lépő hazai politikatudományban kevésbé a liberalizmus, mint inkább a demokrácia győzelméről esik szó, illetve arról, hogy a demokratikus intézményeket hogyan lehetne megteremteni és stabilizálni. A Politikatudományi Szemlében ekkor számos, a demokratikus intézmények alapításával, múködésével kapcsolatos cikket találunk, és a polity elemzése marad a legfőbb tematika az egész korszakban, a 90-es évek végén, a 2000-es évek elején is, amikor a tranzitológia és a konszolidológia kimerül, és megjelennek új, de továbbra is jelen-centrikus irányzatok.

${ }^{5}$ A szerző e tétele alátámasztására az O’Donnel-Schmitter-Whitehead szerzőtriót, a Bruszt-Stark duót valamint Przeworski egy munkáját hivatkozza be. Ugyanerről a témáról - valamivel korábban Herbert Kitschelt adott hosszú nemzetközi áttekintést. Lásd: Kitschelt 1992: 1028-1034.

${ }^{6} \mathrm{~A}$ „történelem fogsága” szókapcsolat még a 2000-es években is visszatér. Lásd: Karácsony 2005.

7 „A világ azon vidékein, amelyek elérkeztek a történelem végéhez, a nemzetközi kapcsolatokban fontosabb szerepet játszik a gazdaság, mint a politika, vagy a stratégia" (Fukuyama 1990: 29). 


\section{KÖZELKÉP - Tanulmányok}

Nagyon érdekes ugyanakkor megfigyelni, hogy a Szemlében publikáló külföldi szerzők - nagyjából azon a nyomvonalon haladva, amit a tranzitológia nemzetközi ágáról szólva írtam - mennyire differenciáltan közelítik meg az intézményalapítás kérdéskörét. Az egyik ilyen az intézmények tágabb, komplexebb értelmezése. Claus Offe például arról ír, hogy az átmenetek során létrehozott intézmények „természetesen nem olyanok, mint az eredetiek. Meg is indokolja, miért: „a „másolt” és átültetett intézmények, mivel nem rendelkeznek azzal az erkölcsi és kulturális infrastruktúrával, amelyre az „eredeti” támaszkodhatott, valószínúleg nagyon eltérő és gyakran a várttal ellentétes eredményeket produkálnak" (Offe 1994: 21). Michael T. Greven még tovább megy, amikor nem a „másolásban” óhatatlanul elkövetett hibákat tartja fontosnak, hanem azt, hogy maguk a „mintaadó” intézmények veszítették el 200 év óta szinte szakadatlanul meglévő történelmi teljesítőképességüket. Olyan területeken, mint például az emberi jogok, a szociális jólét vagy a törvények uralma, a nyugati társadalmak „történelmi küszöbhöz” érkeztek, s a küszöbön átlépve már egyáltalán nem egyértelműek ezen intézmények előnyei (Greven 1995). ${ }^{8}$

Megint más kritikával közelít a témához a Plasser - Ulram szerzőpáros. Ők egyenesen a demokratizálódás-elmélet fősodrával vitatkoznak, amikor azt vetik fel, hogy „az általános demokratizáció-elmélet kidolgozására tett kísérletek nem túl biztatóak. A kelet-európai demokratizációs folyamatok egyenes vonalú, töretlen fejlődéséhez füzött naiv reményeket eloszlatták a váratlanul támadt hatalmi ürök, az új bizonytalanságok és a reformországokon belül és egymás között felerősödött feszültségek." (Plasser - Ulram 1995: 22) ${ }^{9}$ Miközben azt is megállapítják, hogy hiányzik egy konszenzusszerűen elfogadott modell.

A legátfogóbban azonban a Kopecky - Mudde szerzőpáros tekint rá a témára. Fó tézisük szerint a tudományos közösségen belül „hatalmas zürzavar uralkodik abban a tekintetben, hogy pontosan mit is jelent a demokratikus átmenet és konszolidáció" (Kopecky - Mudde 2000: 51). Izgalmas az a felvetésük, hogy a kutatói érdeklődés túl hamar fordult a demokratikus konszolidáció kérdései felé, összemosva ezzel az átmenet és a konszolidáció fogalmait. A fogalmak összezavarása oda vezetett, hogy az igazi kérdés - amit ők a demokrácia tényleges „elültetésének” neveznek - nem kapott kellő figyelmet (uo.). Mindezeken túl megfogalmaznak két lehetséges kitörési pontot is: az átmenetek során felmerülő állam- és nemzetépítés kutatásának szükségességét; valamint az átmenetre ható nemzetközi tényezők kutatását. Az előbbi

\footnotetext{
${ }^{8}$ Fontos észrevenni, hogy ezek a kritikák még jócskán az internet, a Facebook és a „társadalmi demokratizálódás" korszaka előtt hangzanak el. Most nem is ebből a szempontból értékelem őket, hanem abból, hogy rámutatnak egy sokszor egyértelműnek tűnő fogalom („a demokratikus intézmények”) bonyolult természetére.

${ }^{9}$ Dankwart Rustow éppen azt hangsúlyozta alapművében, hogy az ilyen egyetértést lehetetlen létrehozni, hiszen nagyon sok különböző aktor-motivációból jönnek létre a cselekvések. Lásd erről első tanulmányom vonatkozó részét: Csizmadia 2018: 105-107.
} 


\section{KÖZELKÉP - Tanulmányok}

kapcsán szóba hozzák, hogy az államépítés tanulmányozásához a demokratizálódás első, nyugat-európai hulláma adhat jó impulzusokat; az utóbbi kapcsán pedig azt mondják, hogy a nemzetközi dimenzió lényegesen fontosabb szerepet játszik, mint a dél-európai és a latin-amerikai átmenetekben (uo.). ${ }^{10}$ Kopecky és Mudde írása azért is különösen érdekes, mert azon írások (egyébként ebben az időszakban nem túl nagy) számát gyarapítja, amelyekben a jelenbeli folyamatok összehasonlító vizsgálatán túllépő igények is megfogalmazódnak. Ám ez az igény a hazai politikatudományban nem válik valóra.

A magyar tranzitológia először is osztozik abban a nyugati optimista véleményben, hogy itt egy egyenesen előrehaladó folyamat indul meg a demokratizálás által. A folyamat magában foglalja először az intézményeket, de aztán ezen túl az emberekre, az állampolgárokra is ki kell terjednie. Az egyik legaktívabb szerző ebben az időszakban Ágh Attila, aki a Magyarország Politikai Évkönyve című kiadványsorozat 1992-es évfolyamában - az első éveket még az átmenet időszakához sorolva - azt jósolja: „az 1990-es évek végén kezdődhet a konszolidáció időszaka, mint az új rendszer kibontakozása és a saját alapra való helyeződése" (Ágh 1992: 16). Ugyanakkor a külső közegnek a magyar demokrácia konszolidálását illető jótékony szerepét is hangsúlyozza. Ugyanis nem sokkal cikke megírása előtt, 1991. december 16-án írják alá Magyarországnak az Európai Unióhoz való társulási szerződését, s így egy új „pozitív kényszerpálya" körvonalai rajzolódtak ki, egy olyan külső erőcentrumé, amely megszabja a belső haladás általános irányát az európai intézményrendszer normái szerint, s így védelmet nyújt az autoriter tendenciák ellen (uo.). ${ }^{11}$

Ugyanakkor Ágh bevezeti a „strukturális patthelyzet” fogalmát is, amellyel arra utal, hogy noha a parlamenti rendszer (és nem a demokrácia általában) konszolidált, mégis számos kérdés megoldatlan, mert az ellenérdekelt szereplők között patthelyzet áll fenn. Ilyen a) a kormány- és az ellenzéki pártok viszonya; b) a kormányfó és a köztársasági elnök viszonya; c) a parlamenti többség és az alkotmánybíróság viszonya" (uo. 20). A dolgozatban Ágh itt már - annak a konszenzuális értékrendnek a nevében, amely korábban kiformálódni látszott - kemény kritikát is megfogalmaz a parlamenti többséggel szemben: „A fejlett demokráciákban az egyszerű parlamenti többség hatalma korlátozott...mivel a demokrácia lényege nem a többség diktatúrája, hanem a kisebbségek védelme és az ellensúlyozó elnök, rivális hatalmi centrumok összjátéka." (uo. 26).

${ }^{10} \mathrm{Az}$ állam- és nemzetépítés elmaradása - mint a demokráciák visszarendeződésének egyik okaként történő megnevezése - az időben előrehaladva egyre gyakoribbá válik. Az utóbbi időben az államépítést egyenesen, mint új fejlődési paradigmát határozzák meg. Lásd erről: Marquette - Beswick 2011. Giovanni Carbone felhívja a figyelmet arra, hogy az államépítés nem ugyanaz, mint a jól működő állam (Carbone 2015).

${ }^{11}$ A pozitív kényszerpálya kifejezés nyilvánvaló utalás arra, hogy a magyar köznyelvben a „kényszerpálya" kifejezés a korábbi évtizedekben döntően negatív tartalmú. Lásd például: Ránki 1983. 


\section{KÖZELKÉP - Tanulmányok}

A mából visszatekintve két észrevételt tehetünk ehhez. Az egyik az, hogy Ágh helyesen veszi észre az átmenet utáni helyzetben strukturálisan benne rejlő bizonytalanságot, azt, hogy nem egyértelmű, milyen jellegű a politikai rendszer. Ám az Antall-kormány kapcsán „a többség diktatúrája” kifejezés használata világossá teszi, hogy a szerző demokrácia-felfogásában a hangsúly - a nyugati átmenet-elméletekhez hasonlóan - a liberalizmuson és nem a demokrácián van. Ezt akár hangsúlyváltásnak is tekinthetnénk, hiszen a magyar átmenetben korábban a demokratikus jelleg tűnik hangsúlyosnak, különösen, ha a demokráciát a diktatúra meghaladásának ellenszereként értelmezzük. A liberális érték-elem pontos mibenlétéről ugyanakkor az 1990-es évek elején még nem ad egyértelmű eligazítást számunkra sem a demokratikus ellenzék (mint a legnyugatiasabbnak mondható ellenzéki csoport), sem a többi késő kádári elit tevékenysége. Ezek közös eleme - mint utaltam rá - az erősödő nyugatosság, de ebben a fél évtizedes hagyományban viszonylag még gyenge a liberalizmus szerepe.

Ha ez így van, akkor ebből levonhatunk egy óvatos következtetést a kezdeti „konszenzus-elmélet" érvényességére vonatkozóan. Általános érvényű konszenzusról ugyanis akkor beszélhetnénk, ha túlmenően Magyarország nyugati orientációján (amelyben, mint láttuk a 80-as évek második felének elitjei egyetértettek), konszenzus lett volna a liberalizmus „demokrácia-fegyelmező” szerepének megítélésében is. Ilyen típusú konszenzus azonban nem létezik; sőt ellenkezőleg: a pártokba rendeződő politikai elit gyorsan polarizálódik. Nem véletlen beszél egy évvel iménti cikke után Ágh Attila „a túlpolarizáltság veszélyes állapotáról” (Ágh 1993: 42), hozzátéve a másik fó problémaforrást is: a polarizáció azért fokozódott, mert a kormányzat megpróbálta feloldani a „strukturális patthelyzetet” (uo. 52).

A „strukturális patthelyzet”, az „egyensúlytalanság”, az induló magyar demokrácia „eldöntetlen modellje” utáni helyzet később természetesen másoknak (és nemcsak hazai szerzőknek) ${ }^{12}$ szúr szemet. De a hazai tudományos közbeszédben (és a tágabb közéletben) ezt a kezdettől jelen lévő polarizálódást mégsem súlyának megfelelően kezelik, s úgy tesznek, mintha ez a patthelyzet vagy egyensúlytalanság nem is létezne, s Magyarországon a konszenzuális demokrácia modellje állna fenn. A logika egyszerű: az átmenet során győztes teóriából a konszenzuális modell következik, s minden kísérlet, amely e felől a többségi felé akarja elmozdítani a rendszert, a rendszerváltó liberális elveknek - $\mathrm{s}$ azon belül a demokrácia konszolidálása elvének - mond ellent.

1998-as dolgozatában Ágh még tovább megy, amikor azt mondja: a konszolidáció jegyében lezárulhat Magyarország 10-12 év óta tartó válságciklusa (Ágh 1998). Erre az optimizmusra a pártrendszer múködésében tapasztalható - s térségben út-

${ }^{12}$ A modell-probléma bizonytalanságáról és az ebből fakadó következményekről a legátfogóbb és legjobb feldolgozás: Roberts 2006. 


\section{KÖZELKÉP - Tanulmányok}

törőnek tekinthető - három innováció számbavétele sarkallja: a) Magyarországon (szemben jó néhány térségbeli országgal) valódi többpártrendszer jött létre; $b$ ) a 90-es évek második felére egy megújult, reformált nagy balközép pártról beszélhetünk; c) 1997-ben megindult a konszolidált pártrendszer múködéséhez szükséges jobbközép pólus integrációja is (uo.).

Azt, hogy a szerzőnek „elfogadó” a véleménye az első Orbán-kormányról, bizonyítja, hogy az Orbán-kormány karakterét egy évvel később - ellentétben az Antall-kormány megítélésével - konzervatív-liberálisnak tekinti (Ágh 1999). Ugyanakkor ebben a dolgozatban a szerző ugyanúgy érvel, mint az Antall-kormány idején írott dolgozatában: a kormány múködésének eredményeképp a magyar demokrácia elmozdult a konszenzuálistól a többségi demokrácia felé (uo.). Ugyanakkor van itt egy új elem is: „a konszolidáció időszaka Közép-Európában jóval hosszabb lesz, mint a konszolidáció újabb évtizede délen" (uo. 39). Aminek az a magyarázata, hogy a 80-as évek bipoláris világrendjében Nyugat-Európa erősebben támogatta a déli országokat, mint a 90-es évek egypólusú világában a kelet-közép-európai országokat (uo.).

A jelen „megnyúlását” bizonyítandó Ágh bevezeti a korai és az érett konszolidáció fogalmát. A korai konszolidáció korát még a konfliktusok mélyülése jellemzi, s ekkor előfordulhat, hogy a pártpolitikai patthelyzetet az egyik fél (esetünkben a jobboldal) a kvázi-kétpártrendszer felé való elmozdulással igyekszik „véglegesíteni, azonban azt is jelzi, hogy a korai szakaszban is törekednie kell a két meghatározó pártnak az együttmúködés új formáinak kialakítására. ${ }^{13}$

2001-es írásában tovább igyekszik értelmezni a konszenzus és a fragmentálódás fogalmait. Most is adottnak veszi a rendszerváltás konszenzuális örökségét, s azt állítja: a menet közben meginduló fragmentálódás épp emiatt az erős hagyomány miatt jár a környező országokéhoz képest nagyobb feszültséggel (Ágh 2001). Tovább füzvén a konszolidációs szakaszról szőtt elméletét, kitér az érett konszolidáció természetére is: E szerint érett konszolidáció akkor van, amikor 1. a politikai rendszer támogatottsága független a pártpolitikai polarizáltságtól, s a választáson alul maradó pártok hívei is elégedettek a demokráciával; 2. kormányváltás esetén is érvényesül a szakpolitikai folytonosság.

A hazai irodalomban sokáig él ez az Ágh által megfogalmazott konszolidációs tézis. Egyedi Zsolt például 1998-ban, a Politikatudományi Szemlében arról ír, hogy a magyar demokrácia konszolidáltnak tekinthető. A konszolidáció nem más, mint a

${ }^{13}$ Ágh a hazai szerzők között szinte egyedülálló módon s visszatérően a nemzetközi (döntően európai uniós) történésekből vezeti le az itthoni követelményeket. Ahogy annak idején megállapította, hogy Magyarország 1991-es EU-s társulási szerződése katalizátora a további itthoni történéseknek, tíz évvel később, az EU-csatlakozáshoz közelebb „megtalálja” a külső „pozitív kényszerpálya” újabb követelményét, az Agenda 2000 Programban. Ez részletes jogi politikai harmonizációs feladatokat írt elő a csatlakozni kívánó országoknak. 


\section{KÖZELKÉP - Tanulmányok}

politikai viszonyok és a konfliktusmegoldó folyamatok mintáinak kikristályosodása (Enyedi 1998). Az 1990-es évek végén - bár Ágh fentebbi mondatában már szerepel az „autoriter” szó - a magyar demokráciában még nem olyan kiélezettek a viszonyok, mint később. S még G. Márkus György is pozitív példaként idézi be Claus Offét, aki szerint Magyarország az egyetlen ország Kelet-Közép-Európában, ahol identitáskonfliktusok nem állnak a konszolidáció útjában (G. Márkus 1997). ${ }^{14}$ Ágh még 2001-ben is lehetségesnek tekinti, hogy a konszolidációs tematika fogalomkörében maradva Magyarországon a konszolidáció újabb szakasza kezdődjön, ami már a társadalom konszolidálását jelenti.

\section{A jelen-centrikus tudományos és politikai irodalom fókuszának koncentrálódása a Fidesz vizsgálatára}

De a pártpolitikai mezőben bekövetkező változások - mindenekelőtt A Fidesz pólusváltása, majd kormányra kerülése - már módosítják az elemzői optikát és a 90-es évek végén már nem annyira az intézményépítés és a konszolidáció a fó téma, hanem a Fidesz felemelkedésének vizsgálata. A magyar politika polarizáltságára már eddigi szerzőink is tettek megállapításokat, de a polarizálódás és az új keletű konfliktusok leírására a 2000-as évek elejétől kerül sor. Míg az 1998-ban hatalomra kerülő Orbán-kormány első évében még várakozás teli a hangulat, addig az Orbán-kormány működésének második, harmadik éve már több szerző kritikáját is kiváltja. Sárközy Tamás például az általa érzékelt „a győztes mindent visz” modell alkalmazását veszélyesnek és az ország hosszú távú érdekei szempontjából hátrányosnak tartja" (Sárközy 2002: 58). Azt írja: a jogállamiság keretei 1989-91 között kialakultak, s „egy polgári jogállamban jogbiztonságnak kell lenni, s a közhatalmat nem lehet korlátlanul gyakorolni" (uo. 69). Ugyanakkor a szerző egy érdekes ellentmondásra is felhívja a figyelmüket, amikor az 1989-91-es alkotmányos modell jogállami sérüléséról beszél. Egy másik területen ugyanis az Orbán-kormány nem hogy eltérne a korai alkotmányos modelltől, hanem éppen megvalósítja azt: „Az Orbán-kormány struktúrája az első, amely szerkezetében teljesen alkalmazkodott az 1989-90-es alkotmányos alaphoz, a kancellári rendszerhez." (uo. 60). Ez a megjegyzés ismét csak ráirányítja a figyelmünket az „eredeti” modellben rejlő ambivalenciára, illetve a modell sokféle értelmezhetőségére.

A legátfogóbb kritikát talán (az akkor még politikus) Hack Péter gyakorolja, aki párhuzamot von az Orbán-kormány hatalomgyakorlási technikája és közjogi felfogása valamint a néhai MSZMP 1989-es felfogása között, megállapítván: a Fidesz

${ }^{14}$ Nagyon érdekes, hogy a 2010-es években megjelenő nyugati elemzések már „érthetetlenül” optimistának tekintik az átmenet kora utáni évtized nyugati optimizmusát. 


\section{KÖZELKÉP - Tanulmányok}

eltávolodott attól a felfogástól, amelyet 1989-ben az Ellenzéki Kerekasztal pártjai képviseltek (Hack 2002). A szerző megállapítja azt is, hogy a parlamentáris rendszer létrejöttével Magyarország jó esélyt kapott arra, hogy „az antidemokratikus hagyományokat magunk mögött hagyjuk (...) kétségtelen viszont, hogy az Orbán-kormány idején végrehajtott antidemokratikus fordulatnak erős gyökerei vannak az 1989 előtti, de az 1945-öt megelőző politikai kultúrában is" (uo.). Ez egy igen erős - ráadásul a történelmi fejlemények fontosságára utaló -, ám kibontatlan megjegyzés, mint ahogy az is, hogy az Orbán-kormány esetében már nem a demokrácián belüli modellváltásról, sokkal inkább egy már nem demokratikus modellről van szó. Érdekes, hogy miközben Sárközy éppen azért ismeri el a kormány teljesítményét, mert az (az 1989-es alkotmányos alapelveknek megfelelően) megvalósítja a kancellári demokráciát, Hack értelmezésében ez már nem kancellária-demokrácia, nem is elnöki kormányzás, hanem a hatalomgyakorlás kontrolljának felszámolása. ${ }^{15}$

Ezekből az idézetekből az látszik, hogy a jelen folyamataira koncentráló domináns értelmezések középpontjában döntően két kérdés áll: a liberális alapelvek hangsúlyozása és „számonkérése” valamint a demokrácia ezen alapelvek mentén történő konszolidálása. Az idézett szerzők kivétel nélkül úgy vélik, hogy a Fidesz kormányzása „veszélyes” az 1990 után kiépült magyar demokráciára, s már 1998 és 2002 között megfogalmazzák azokat a kritikákat, amelyek majd a Fidesz második ciklusa idején, 2010 és 2015 között állnak össze egy egységes demokráciavédő narratívába. ${ }^{16}$

De itt még nem tartunk. Ahogy az imént láttuk: a Fidesz első kormányzását liberális nézőpontból éri a legtöbb kritika, de a kritikákban egy minőségileg új szakasz kezdődik akkor, amikor a Fidesz - 2006 után - másodszor kerül ellenzékbe. Ebben a ciklusban (tehát még jóval az előtt, hogy Orbán Viktor, már miniszterelnökként felvállalná, hogy „,illiberális államot” épít) ${ }^{17}$ nemzetközi elemzők részéről elkezdődik az orbánizmus-illiberális veszélyeire való figyelmeztetés. ${ }^{18}$ Hasonlóképpen nagyon

${ }^{15}$ Hack itt Körösényi Andrásnak arra a tételére utal, miszerint az orbáni „prezidenciális” kormányzás a demokrácián belüli karakterváltozást jelent csak: „az alkotmányjogi és politikai értelemben változatlanul fennálló parlamentáris kormányzás keretein belül a kormányzás egy új típusa, a kormányzás prezidencializálódása alakult ki”. (Körösényi 2001: 31)

${ }^{16}$ Ezek a nézetek - nem kis mértékben a nyugat-európai kritikákkal párhuzamosan - baloldali és liberális folyóiratokban és újságokban (az említetteken túl: Beszélő, a Mozgó Világ, Kritika, Élet és Irodalom stb.) fogalmazódnak meg. Külön érdekesség azonban, hogy a 2000-es évek közepétől erős kritika jelenik meg konzervatívnak tekinthető orgánumokban is. A Kommentár című folyóiratban jelenik meg például Körösényi András (2007) sok vonatkozásban a bal-liberális kritikákon is túltevő írása.

${ }^{17}$ Lásd a 2014-es nyári tusnádfürdői beszédet. Magyar Nemzet, 2014. július 29.

${ }^{18}$ Sokan már a 2006-2010 közötti periódusban úgy látják, hogy az akkor ellenzéki Fidesz komoly veszélyt jelent a liberális demokráciára. Ivan Krastev például a lengyel Jog és Igazság hatalomra kerülését látja itt fordulópontnak, s ekkortól számítja a liberalizmus „különös halálát” (Krastev 2007). De igazán az illiberális Orbántól való félelem - különösen a nemzetközi sajtóban és politikatudományi irodalomban 2010 után erősödik fel. Lásd például: Mudde 2011. 


\section{KÖZELKÉP - Tanulmányok}

kritikus cikkek és tanulmányok jelennek meg hazai szerzőktől is: az elmúlt tíz évből tanulmányok és cikkek sokaságát citálhatnánk a magyar jobboldal „radikális fordulatának" alátámasztására. Természetesen ezek átfogó szemlézésre nincs módon; csupán két témakörre koncentrálok. Egyrészt igyekszem röviden összefoglalni azokat az írásokat, amelyek arra keresik a választ, hogyan tolódott el „végérvényesen” a magyar jobboldal egy antiliberális és „zsákutcás” irányba. Másrészt bizonyos írások alapján igyekszem rekonstruálni a liberális paradigmának fejlődésében a 90-es évek elejéhez képest két újnak mondható elemét: a liberalizmus véglegesnek tűnő győzelmét a demokrácia felett, illetve - ehhez szorosan kapcsolhatóan - a globális nézőpont győzelmét a nemzetállam felett.

Láthattuk, hogy a Fidesz demokrácia-felfogását illető hazai elemzői és politikai kritikák már első kormányzása idején felerősödnek, s érdekes módon a párt ellenzékbe kerülésével ezek a kritikák nemhogy csökkennének, hanem még fokozódnak is. Sok oka van annak, hogy ezek a kritikák 2002 és 2006 között fokozódnak a baloldali-liberális közvélemény körében. A fokozódó kritikák döntően három indokot említenek. Az első: a Fidesz a 2002 tavaszán sokáig nem fogadja el a választások elvesztését, ${ }^{19} \mathrm{~s}$ a kormányoldali értelmiség szerint zavart akar kelteni a váltógazdálkodás kialakult rendjében és destabilizálni akarja a magyar demokráciát. ${ }^{20} \mathrm{~A}$ második: a választások tisztaságának kétségbe vonásával a Fidesz nem pusztán átmeneti zavart akar kelteni, de tartósan polarizálni is akarja a politikai életet és a pártrendszert. ${ }^{21} \mathrm{~A}$ harmadik: a Fidesz új pártszervezési formája, nevezetesen a polgári körök szervezése gyengíti a politika parlamentáris kereteit és magában rejti (majd teljes mértékben meg is valósítja) a populizmus csíráit.

Az, hogy a magyar demokrácia azért mégsem olyan stabil, mint amilyennek az első szűk másfél évtizedben tűnt, az első bizonyítékot a 2004-ben bekövetkező kormányfő-csere szolgáltatta. Ilyen jellegű idő előtti váltások más környező országokban korábban is történtek (például Csehországban vagy Lengyelországban), Magyarország azonban ebből a szempontból is a térség legstabilabb országa volt 1990 és 2004 között. A későbbi változás előszeleként értelmezhetjük azonban a 2002-es MSZP-győzelem, majd koalíció-alakítás egy speciális sajátosságát: ellentétben a korábbiakkal nem „fölös többségi”, hanem csak „minimális többségi” kormánykoalíció alakul (Vö. Nikolenyi 2004: 129). Ez különösen a 12 éves „fölös többségi” hagyo-

${ }^{19}$ Lásd erről: Kéri-Petschnig 2003: 135.

${ }^{20} 1990$ és 2002 között leginkább a négy évenkénti kormányváltások ritmizálták - és stabilizálták - a magyar demokráciát. A Fidesz nem állt messze attól, hogy 2002-ben megtörje ezt a trendet és egy második ciklusra is kormányzati pozíciót szerezzen. Ez végül mégsem sikerült.

${ }^{21}$ Kéri és Petschnig évértékelőjében a politikai polarizálódás 12 stációját említi (lásd: Kéri-Petsching 2003: 133-137). Én a polarizálódást önálló tételként azonosítom, elismerve, hogy az számos eseményben és folyamatban testesült meg. 


\section{KÖZELKÉP - Tanulmányok}

mány után tűnik fel számunkra. ${ }^{22} 2002$ után tehát egyszerre indul ki meg két folyamat: a) a kormányoldalon belül nő a kisebbik koalíciós párt befolyása a nagyobbik rovására; $b$ ) ettől nem függetlenül erősödik a liberális értelmiség befolyása a jobboldali politika fogalmi leírására. Mindazonáltal mindkét konfliktus majd a következő ciklusban, 2006 és 2010 között éleződik ki: a Fideszről ebben az időszakban fogalmazódnak meg az első átfogó, a Fidesz populista pártként leíró elemzések; s ekkor éleződnek ki a „minimális koalíción” belüli ellentétek is, amelyek eredményeképp 2008-től az MSZP kisebbségi kormányzást folytatva vezeti az országot. A továbbiakban csak a Fidesz szerepfelfogását illető, erősen kritikus megközelítésekre koncentrálok. ${ }^{23}$

Kezdjük az időben korántsem első, de annál élesebb kritikával, amelyet konzervatív oldalról kap a Fidesz. Szerzője az a Körösényi András, aki 2001-ben a kartellpárt-tézissel és a prezidenciális kormányzásra való áttérés tézisével igyekszik bizonyítani a Fidesz-kormány újszerűségét és annak a demokratikus rendszeren belüli relevanciáját (Körösényi 2001), s aki 2005-ben, a vezérdemokráciáról írott könyvében igen részletesen beszél a politikusi akaratról, sőt önkényességről (lásd: Körösényi 2005: 135). 2007 végén a szerző már nem beszél a „kormányzás prezidencializálódásáról", s pozitív értelemben vett vezetői akaratról sem; ezzel szemben úgy ítéli meg, a Fidesz eltávolodott korábbi önmagától s 2002-2007 között követett politikája több szempontból is komoly kritikának vethető alá. 1. Megbukott a Fidesz minden jobboldali erőt egy táborba tömöríteni kívánó „néppárti” stratégiája s ezzel szemben egy decentralizáltabb, platformosodó Fidesz-müködésre kellene áttérni (Körösényi 2007). 2. A Fideszben autokratikus vezetési stílus alakult ki, s egyáltalán nem biztos, hogy egy ilyen vezetési stílussal - még ha lehetséges is - „érdemes” megnyerni a soron következő választást (uo.). 3. Zsákutcába jutott a világos politikai és szakpolitikai programokat megfogalmazni képtelen politikai stratégia (uo.).

Mindezek következtében - állítja a szerző - a polgári politika elmozdult a populizmus felé, ami - egy polgári párt számára - súlyos hiba. „Hiba egyrészt azért, mert így hosszabb távra is átengedi a jobboldali-liberális pozíciót a gazdasági dimenzióban a szocialista-szabaddemokrata koalíciónak. Másrészt azért, mert így a középosztály pártjából egyre inkább a „vesztesek” pártjává válik (...) Hiba harmadszor azért, mert a populizmussal a Fidesz elveszíti az elitcsoportok többségének támogatását" (uo. 101).

${ }^{22}$ Fölös többséginek nevezzük azt a koalíciót, amelyben van egy úgynevezett „potyautas” párt is, amely nélkül múködhetne és többségben maradhatna a koalíció. Ilyen párt Magyarországon a KDNP az Antall-, az SZDSZ a Horn-, és az MDF az Orbán-kormányban. S ilyen potyautas párt nincs a 2002-ben létrejövő Medgyessy-kormányban. Vö. Nikolenyi 2004: 129.

${ }^{23}$ A bal-liberális oldalon belüli konfliktusokról, illetve a kisebbségi kormányzásról lásd: Petrétei 2009, Stumpf 2009. Hogy a kisebbségi kormányzás mennyire reális opció már korábban is, arról lásd a miniszterelnök háttérintézményének, a Demos-nak a kutatását: Hajduk-Tornai szerk. 2007. 


\section{KÖZELKÉP - Tanulmányok}

Miközben Körösényi (mint jobboldali teoretikus) kifejezetten erős (olykor a baloldali-liberális kritikák hevességével vetekedő) bírálatot tesz közzé, a Fidesz a 2006-os őszödi események tükrében nemhogy nem indul el a Körösényi által javasolt irányba, de éppen ellenkezőleg cselekszik. Hogy miért is tesz így, arra nagyon érdekes magyarázatot ad két kollégám kiváló elemzése (Róbert - Papp 2012). Ők azt állapítják meg - s ezek nyilván a Fidesz vezetői előtt sem voltak ismeretlen információk -, hogy az MSZP 2006-os választási győzelmét olyan szavazóknak köszönhette, akik korábban nem kötődtek a párthoz s ez nagymértékben bizonytalanná tette a szavazótábor távlati magatartását (Róbert - Papp 2012). Ugyancsak beszédes adat lehetett a Fidesz meglévő irányának fenntartásához, hogy míg 2002-ben a Fidesz-szavazók 63\%-a, addig 2006-ban már 71\%-a volt elkötelezett (uo.). S hogy a Fidesz stratégiaalkotói végül is nem számoltak rosszul, azt bizonyítja, hogy 2010 áprilisában az MSZP 2006-os szavazói között körülbelül 15 százalékponttal csökkent a Fidesz-KDNP elutasítása. Erre írja Róbert Péter és Papp Zsófia, hogy ők ezt az „identitásvesztés jelének” tekintik (uo. 56).

Ebből a kutatási beszámolóból mintha nem az rajzolódna ki, hogy miközben a Fidesz eltávolodik korábbi polgári karakterétől, elveszítené identitását. Valószínűleg az ilyen jellegü információk is hozzájárulnak ahhoz, hogy a Fidesz nem a hagyományos konzervatív-polgári, hanem a keresztény-plebejus identitást választja ekkoriban magának.

Az nyilvánvaló, hogy a magyar politikában egy különlegesen érdekes változás zajlik le az 1990-es évek közepétől, s ez a Fidesznek a liberális pólustól való eltávolodása, majd az arról való leválása. Ezt a hazai politikatudomány a mainstreamnek számító fogalmi keretek között elemzi, s megállapítja róla, hogy a Fidesz már a 90es évek végén kezd eltávolodni a demokratikus értékektől, illetve nem is annyira a demokratikus, mint inkább a liberális értékektől, vagy még pontosabban a liberális demokrácia értékvilágától.

\section{Fidesz jobbratolódásáról és radikalizálódásáról szóló politikai és tudományos kritikák 2006 és 2017 között}

A Fideszt ekkor már általánosan övező negatív bal-liberális megítélés mellett, érdemes rámutatnunk arra is, hogy - ha rövid ideig is - létezik a jobboldal kritikájának egy mérsékeltebb vonulata is, s ez éppen a regnáló miniszterelnök, Gyurcsány Ferenc nevéhez köthető. Gyurcsány több írásban is foglalkozik a Fidesszel. Az egyiket fél évvel az őszödi botrány kirobbanása után, a másikat a 2008-as pénzügyi és hitelválság megindulása előtt írja, s mindkettőben olyasmivel kísérletezik, amivel rajta kívül nem sokan a bal-liberális oldalon. Először is nem pusztán csak kritizálja a Fideszt, hanem megpróbálja meg is érteni ellenfelét; továbbá a korabeli Magyarország problémáit igyekszik történetileg (is) értelmezni. A kísérlet kudarca azonban boríté- 


\section{KÖZELKÉP - Tanulmányok}

kolható volt, hiszen a miniszterelnök - írásos offenzíváját megelőzően - nem tudta kezelni az „Őszöd-szindrómát”. ${ }^{24}$

Pedig a 2007. januári, Szembenézés című dolgozatának bevezetőjében ezt írja: „Nem állok középen, de szeretném jobban érteni riválisaimat... Megmerevedett álláspontok és rögzült politikai szerepek közepette szeretnék tenni egy lépést a kölcsönös megértés irányába". ${ }^{25}$ De folytatja is, s kijelenti: elismeri a jobboldal indulási hátrányát. A jobboldalnak „nem voltak intézményei, hiányozott saját sajtója, töredékesek voltak társadalmi kapcsolatai. A baloldal nem nagyon vett tudomást erről a helyzetről, a jobboldal pedig erre a méltánytalanságra nemegyszer indulatos daccal, radikális médiapolitikával válaszolt".26

Ez egy kevésbé polarizált országban akár egy nagykoalíció létrehozásának is előfeltétele lehetett volna. A szöveg meg is mondja, miért kellene, és mire épülhetne egy ilyen nagykoalíció: „Azok a nemzetek lettek sikeresek, amelyeknek meghatározó közéleti, politikai tényezői közös modellel tudtak válaszolni a globalizációs kihívásra". Ám az adott belpolitikai konstellációban az ilyen felvetések semmilyen pozitív kimenetellel nem bírtak a kormány-ellenzék viszony javítását illetően. Ezért hiába jön Gyurcsány második kísérlete, a Megegyezés. Magyarország megújításának lehetséges irányairól című írás, az nem tudja pozitív irányban befolyásolni a helyzetet. ${ }^{27}$

${ }^{24}$ A „szindróma” szót olyan értelemben használom, hogy az őszödi beszéd rendkívül különböző megítélésék metszéspontjába került. A miniszterelnök például egy interjújában nem sokkal utána azt mondja: Magyarország egészen 2006 szeptemberéig „a régió legstabilabb demokráciája”, ám az utcai zavargások nyomán „a világ egy másik képet ismert meg rólunk”. Lásd: Gyurcsány Ferenc interjúja, Gyurcsány 2006: 11. Ennek az értelmezésnek a része az is, hogy az őszödi beszéd valójában „igazságbeszéd” Elfelejtkeznek azonban arról, hogy a beszéd kulcsmomentuma nem az, hogy új alapokra akarja helyezni a magyar politikát, hanem a „hazudtunk” motívum. Politikai újrakezdéséhez a hazugságokért való elnézés- és új mandátumkérés vezethetett volna. Lásd erről: Csizmadia 2014: 159-187 és uo. 295-303. A másik értelmezés kezdettől hazugbeszédnek minősítette az őszödi beszédet. Orbán Viktor - vélhetően - a beszéd ismeretében írta meg 2006 nyarán cikksorozatát a Magyar Nemzetben: Lásd: Orbán Viktor: Vízválasztó I-III. július 29., augusztus 5.; szeptember 9.

${ }^{25}$ Gyurcsány Ferenc: Szembenézés. 23 pontban hibákról, tanulságokról, tennivalókról. Népszabadság, 2007. január 26. Ez a dolgozat is illusztrálja: a 2000-es évek eleje óta változás következett be; ekkor már nem lehet teljesen mellőzni a történelmet ahhoz, hogy a jelen problémáira választ keressünk. A szerző a 23 pont közül az elsőt („Baj van a rendszerváltással?”) így kezdi: „Sokszor visszatérő állítás, hogy minden a rendszerváltásnál romlott el. Én úgy gondolom, ez nem így van”. Majd hozzáteszi: ha már a történelemhez kell fordulnunk válaszért, akkor azt kell mondani, hogy a problémák a II. világháború után kezdődtek: „a kommunista hatalomátvétellel zökkent ki a magyar történelem a saját, mondjuk úgy, normális kerékvágásából”. Ez zavarba ejtő megfogalmazás, hiszen Gyurcsány itt majdnem azonos állásponton van, mint a Fidesz által 2011-ben elfogadott Alaptörvény preambuluma, amely szerint Magyarország 1944. március 19-től 1990 áprilisáig nem volt szuverén ország.

${ }^{26}$ Uo.

${ }^{27}$ Népszabadság, 2008. augusztus 29. A Fidesz álláspontját már 2006 nyarán világosan kifejezi Orbán Viktor „Vízválasztó” címú cikksorozata a magyar Nemzetben. Ezekben az írásokban - még az őszödi beszéd kiszivárgása előtt vagyunk - Orbán nyilvánvalóvá teszi: „2006-ban nyílt, szervezett hazugság történt" s ily módon a regnáló miniszterelnökkel mindenféle együttműködés elképzelhetetlen. Lásd: A vízválasztó. 1. rész. Magyar Nemzet, 2006. július 29. 


\section{KÖZELKÉP - Tanulmányok}

Holott itt Gyurcsány megint gesztust tesz a saját, nemzeti modellben gondolkodó jobboldal felé. Magyarországnak új modellre van szüksége - írja -, amely „nem más, mint sajátos, ránk jellemző társadalmi-gazdasági egyensúly, amelynek belső arányairól bizonyos határok között magunk dönthetünk". ${ }^{28}$

A mai szemmel meglepőnek mondható gyurcsányi Fidesz-értelmezéshez hasonló megközelítést 2002 és 2010 között szinte egyáltalán nem találunk a bal-liberális oldalon, 2010 után pedig végképp nem. ${ }^{29}$

A legjellemzőbb és legkeményebb tónust az a Debreczeni József képviseli, aki akkor még független publicista, s ma már a Demokratikus Koalíció alelnöke. Debreczeni több írásban is (Debreczeni 2006, 2009) foglalkozik a Fidesz antidemokratikus „átváltozásával”. A korábbi írásban - Orbán-idézetek elemzése alapján - a szerző kijelenti: „az orbáni populizmus bizonyos vonásai erősen emlékeztettek egyes két világháború közötti szélsőjobboldali jelenségekre" (Debreczeni 2006: 27). Itt tehát ha teljesen negatív színezetben is - újra előjön a történelem, s a történelmi összehasonlítás nyomán jut a szerző arra a következtetésre, hogy „Orbán már rég nem a magyar közélet nyelvén szól.” (Uo.) Azt azért „elismeri” a szerző, hogy Orbán nem akar „zsidókat irtani”, de ténykedése eredményeképpen „gátlástalan populistának” látja, akinek legfőbb jellemzője a „gyűlöletkeltés” (uo. 29). A távolabbi történelmi közegben történő elhelyezés mellett (ahol Orbán természetesen nem Bethlen, hanem Gömbös Gyula mai alteregója), Debreczeni a rendszerváltás utáni korszak első miniszterelnökével, Antall Józseffel is összeveti Orbánt: „Antall a híd szerepét töltötte be: a negyvenes években megszakadt magyar jobboldali parlamentáris tradíciót összekötötte a megújult nyugati jobboldalisággal, a kilencvenes évek jelenével" (uo. 32). Őhozzá képest Orbán nem az Antall által képviselt „jó” történelmi tradíciót, hanem a „rosszat” képviseli, s ez által „tönkreteszi a magyar jobboldalt” (uo.). Mindöszsze annyi engedményt tesz, hogy a két rossz (nácizmus és fasizmus) közül Orbán populizmusa „inkább a korai fasizmus, kevésbé a nácizmus szellemiségéhez, politikai kultúrájához és eszköztárához" kötődik (uo. 33). 2009-es cikkében Debreczeni, nem megismételve korábbi véleményét, bekapcsolja Bibó „hisztéria-elméletét” is, megállapítva, hogy a magyar politikai közélet hiszterizálása egyoldalú módon a Fideszhez, s döntően Orbán személyéhez köthető. (Debreczeni 2009: 26-31).

A 2010-es választások előtt kialakul tehát az „új” Fidesz értékelésének fogalmi kerete, amelynek két visszatérő eleme a populizmus és az antiliberalizmus. Hasonló keretek között értékelik a 2010-ben kormányra kerülő jobboldalt a külföldi szerzők is; igaz, a legtöbb mértékadó nyugat-európai szerző nem jut el a náci vagy fasiszta minősítésig. A neves populizmus-kutató, Cas Mudde például az európai radikális-populista pártokról írott, 2011-es elemzésében egyértelműen megkülönbözteti

\footnotetext{
${ }^{28}$ A Megegyezés című Gyurcsány-dolgozatról részletes elemzésemet lásd: Csizmadia 2009: 504-515.

${ }^{29}$ Gyurcsány maga is nagyon eltávolodik 2007-2008-as önmagától, s 2013-2014-ben önmagát a Fidesz-kormány „legádázabb” ellenfelének tekinti.
} 


\section{KÖZELKÉP - Tanulmányok}

egymástól a „far right” (szélsőjobboldal) és a „populistradical right” (populista radikális jobboldal) fogalmát, noha fogalomhasználatból az is világos: a radikális elemet a populista pártok specifikumának tartja. Ám a radikalizmus nem szélsőségesség, mint ahogy a mai populista és a néhai fasiszta pártok összehasonlítása is téves, hiszen (ellentétben a néha fasiszta pártokkal) a populista pártok formális értelemben demokratikusak (hiszen a többség és a népszuverenitás elvére építkeznek), ha nem is liberálisak. Azt viszont szintén kidomborítja, hogy a nem liberális alapokon álló radikális populista pártok közül is van kettő, amely különösen veszélyes a demokrácia reprezentatív intézményeire: Berlusconi és Orbán Viktor pártja. (lásd: Mudde 2011). ${ }^{30}$ Ezzel a vélekedésével Mudde lényegében összegzi a 2010-es évek mainstream nyugat-európai közvélekedését a magyar jobboldal értékelésében.

Ennek az uralkodóvá váló közvélekedésnek a hátterében azonban két jól azonosítható körülmény áll. Az egyik az, hogy a demokráciaelméleten (politikaelméleten) belül a 2000-es években kinyíló vita (a liberális demokrácia két komponense, liberalizmus és demokrácia között) egyértelmúen a liberális demokrácia-felfogás képviselői javára dőlt el. A másik pedig a nemzet versus globalizáció vita, amely azok mértékadó befolyását hozza, akik szerint a nemzetállamok helyébe a nemzetek feletti instanciák lépnek.

Ha ezt a két témát visszavezetjük az átmenet időszakáig, akkor egyfelől azt látjuk, hogy bár a liberális demokrácia már 1990 körül is sztenderd szóösszetétel, az alkotóelemek közötti vitát - megint csak a sikeres átmenet érdekében - nem élezik ki. Holott Giovanni Sartori, neves liberális politikai filozófus klasszikus könyvében ezt írja: „Ne felejtsük el, hogy a demokratikus legitimáció csak addig hatalomkorlátozó erő, míg autokratikus hatalommal áll szemben. Miután az ellenfél megbukott, a szuverén nép megszerezheti annak minden attribútumát: ami egy másik hatalommal szemben a hatalom korlátozója volt, korlátlan hatalommá válhat, ha eltűnt a legyőzött ellenhatalom" (Sartori 1999: 100). Ebben a pontos definícióban minden lényeges benne van, amit a liberálisok fontosnak tartanak; a legfőképpen az, hogy a demokratikus elv nem korlátmentes. Ugyanakkor a demokraták számára a demokrácia (éppen mert az a népszuverenitáson és a többségi elven nyugszik) szinte korlátozhatatlan. Ha pedig ez így van, ezzel voltaképpen megjelöltük azt a konfliktusforrást, amely az átmenet utáni magyar demokráciában is (2010 előtt is talán még mérsékeltebben, utána viszont szélsőségesen) szembefordítja egymással a pártpolitikai és értelmiségi elitet.

Sartori könyvéből (és persze az egész hatalmas nyugati irodalomból) az is világos, hogy itt csak „egy” igazság lehet, hiszen „a modern demokrácia elmélete alapvetően „egy”: a liberális demokrácia elmélete” (uo. 18). Ezt Sartori maga is „mainstream theorynak" nevezi, s ez világosan azt mutatja: a Fidesz értékelésében nem a

\footnotetext{
${ }^{30}$ A témához újabban lásd: Körösényi - Patkós 2015.
} 


\section{KÖZELKÉP - Tanulmányok}

90-es évek végétől kiformálódó konszenzusról van szó; sokkal inkább beszélhetünk egy hosszú történelmi hagyományról, s az Orbán-kormány azért kerül olyan negatív megítélés alá, mert demokrácia-felfogása ellentmond ennek a nyugat-európai hagyománynak. ${ }^{31}$ Ebbe a hosszú hagyományba illeszkedik bele Marc F. Plattner elemzése is, amelyben a szerző elmondja: a két alkotóelem közötti konfliktus kiiktathatatlan, s olykor ez torzulásokhoz is vezethet. A liberális demokrácia nincs védve az ellen, hogy hol a demokraták akarják megerősíteni az általuk háttérbe szorítottnak vélt demokratikus elveket a liberálisok rovására (ekkor alakul ki a populizmus);hol a liberálisok érzik úgy, hogy „túl sok a demokrácia”, és ilyenkor a liberális elvek túlhangsúlyozására kerül sor (ekkor alakul ki a radikális pluralizmus - lásd: Plattner 2010: 87)

Ennek a nagyon invenciózus értelmezésnek van egy nagyon fontos módszertani tanulsága, ha az a kérdést vetjük fel (ami egyébként Plattnernél nem merül fel), hogyan, milyen szemléletmóddal közelítsünk Magyarország elmúlt öt évben tapasztalható válságjelenségeihez. Ezt a pártpolitikai „egyensúly” elvének nevezhetjük, s azt jelenti: az egyik politikai szereplő mozgását önmagában nem szerencsés vizsgálnunk. Erre a szempontra korábban már utaltam, amikor Thomas Kuhn paradigma-elméletének tanulságait latolgattam, illetve amikor a szemléleti alapelvek között kitértem a kölcsönhatások vizsgálatának fontosságára.

A fentebb bemutatott kritikai vélemények képviselői azonban többnyire mellőzik egy összetettebb szemlélet alkalmazását, így aztán a Fidesz „populistává” válását önmagából - a többi párt mozgásától elszakított Fideszből - igyekeznek értelmezni. Holott - Plattner tanulmányából is kiolvashatóan - az igazán termékeny megközelítés a Fidesz átalakulását tekintve az, ha megvizsgáljuk, milyen összefüggés van a liberális demokrácia „demokratikus” komponensének felerősítése (Fidesz) és a liberális komponens esetleges „túlhajtása” (bal-liberális oldal) között. ${ }^{32}$

\footnotetext{
${ }^{31}$ Marc F. Plattner például kimutatja: az egész demokráciaelmélet Amerika alapításához vezethető vissza. Elemzésében kimutatja, miként fogalmazódnak meg a liberális és demokratikus alapelvek együttesen például a Föderalistában, s megállapítja, hogy a liberális demokrácia valójában egy olyan duális/ hibrid rendszer, amelyet az tart életben, hogy a két elv egymást kiegészítve, egymással egyensúlyban érvényesül. Lásd: Plattner 2010: 81-92). Inkább a liberális elemet domborítja ki Belohradsky is (Lásd: 1992: 262-263). Még korábban Raymond Aron fogalmazza meg, hogy „Az alkotmányos rendszerek kezdeti fázisában korlátozni kell a népi követeléseket” (Aron 1955/58; 2005: 116)

${ }^{32}$ Ugyanilyen hibát vét Francis Fukuyama is, amikor - a magyar alaptörvény elfogadása után - vitába bocsátkozik a magyar kormány képviselőivel. Ő sem fordít kellő figyelmet arra, hogy a Fidesz-kormány lépéseit megfelelő kontextusban vizsgálja, s csupán azt tudja megállapítani, hogy az új alaptörvénnyel nem is az a baj, ami benne van, hanem a szereplők szándéka Egy másik blogbejegyzésében pedig azt mondja, vannak sokkal fontosabb dolgok a többség formális hatalmánál, például a hatalom önkorlátozása. Következtetése az, hogy Magyarországon nem az új intézmények fenyegetik a demokráciát, hanem a feltámadó régi politikai kultúra Sajnálatos módon azonban, a „túlfeszülő demokrácia” felé vezető út történéseiről nem szól, így ő is beleesik abba a hibába, hogy mindent csak az egyik oldal hibájának ró fel.
} 


\section{KÖZELKÉP - Tanulmányok}

Egy ilyen, a kölcsönhatásokra kevéssé érzékeny megközelítésből logikusnak is tekinthető, hogy Erin K. Jenne és Cas Mudde egy másik írásban nem csak azt mutatja be, hogyan építette le a Fidesz a liberális intézményeket, hanem azt is latolgatja, milyen szerepet játszhat külföld a magyar liberális demokrácia „helyreállításában”. Természetesen a szerzők (ahogy ezt magyar kormánykörök sokszor feltételezik) nem beszélnek a magyar kormány antidemokratikus eszközökkel történő megdöntéséről. Arról azonban igen, hogy a nyugati hatalmaknak nagyon komoly nyomást kell gyakorolniuk a magyar kormányra, s el kell gondolkodniuk olyan nyomásgyakorlási formák alkalmazásán, amelyek lehetetlenné teszik illiberális reformok bevezetését (Jenne - Mudde 2012: 147-155).

Az elmúlt öt évben a kormánypolitika jellege, s a kritikák iránya nem változik, igazán új elem nem látható a korábbiakhoz képest. A jelen-centrikus elemzők viszszatérően szinte mindig ugyanazokat az elemeket említik, ezekkel azonban - véleményem szerint - nem tudnak közelebb férkőzni a Fidesz által követett politika jobb megértéséhez. De az adott elemzési szemléletből talán nem is férkőzhetnek, hiszen relevánsabb értelmezés szerintem csak a jelenből kilépve, történeti szemléletből adható. Erre teszek rögvest kísérletet, de előtte még röviden megemlítek egy olyan kötetet, amely a mérvadó hazai politikatudomány összegző állásfoglalása az elmúlt huszonöt évről. A magyar politikai rendszer - Huszonöt év után című tanulmánykötetben helyet kapó tizenhét tanulmány elolvasása arról győz meg, hogy itt valóban jelen-centrikus kutatók vállalkozásáról van szó. Nem merném határozottan kijelenteni, de egy első olvasás után nekem úgy tűnik: a történelem szó nem szerepel a kötetben, $\mathrm{s}$ nemigen találunk benne általában vett történelmi látásmódra utaló jeleket sem. Így nyugodtan kijelenthető, hogy a kötet egyértelműen az elmúlt negyedszázad „történelem-mentes” mainstream gondolkodásának csúcskiadványa.

Tartalmi értelemben mindössze egyetlen tanulmányt emelek ki a kötetből: Körösényi András munkáját (Körösényi 2015). A szerző a jelenkoron belül mégis csak történeti szempontot alkalmaz, amikor három részre osztja az elmúlt negyedszázadot: az átmenet idejére, a konszolidáció korára valamint a válság és a rezsimváltás időszakára. Írása ezúttal kevésbé radikális, mint a korábban bemutatott, 2007-es cikk. Most a szerző írása második felében elismeri, hogy nagyon sok negatív változás történt és rengeteg autoriter vonás jelent meg a magyar politikában, a huszonöt év egésze mégis megfelel a Dahl által megfogalmazott poliarchia követelményeinek, azaz a rendszer jellege továbbra is demokratikus (Körösényi 2015). Megismétli továbbá azt a korábbról már ismert nézetét, miszerint - szemben az uralkodó felfogással - a magyar demokrácia kezdettől nem konszenzuális; az elitek között sokkal inkább beszélhetünk átmeneti kompromisszumokról, mint elit-konszenzusról (uo.). Ily módon a Fidesz harmadik kormányzásának időszakában legfeljebb felerősödik, de nem kialakul a nagyfokú polarizáció. A szerző nem gondolja - mint az elmúlt években sokan -, hogy a rendszer átlépett volna egy határt és kikerült volna a de- 


\section{KÖZELKÉP - Tanulmányok}

mokráciából; diagnózisa, hogy ami történt: kormányváltásnál több, de rendszerváltásnál kevesebb. Azaz egy új Fidesz-rezsim jött létre, nagyon sok változással, de a változások elvi jellegű megalapozottsága nélkül (uo.). Az elvi alapozottság hiányát azonban nem látom bizonyítottnak. A magam részéről inkább azt gondolom, hogy ez csak a jelen időperspektívájából tűnik ilyen egyértelműnek, de történelmi nézőpontból már nem.

\section{Konklúzió: Történelmi és jelen-centrikus időszemlélet}

Befejezésül hadd térjek vissza két részes dolgozatom egészére, illetve írásom fő mondanivalójára. Döntően egy viszonylag ritkán tárgyalt kérdéssel foglalkoztam. Azzal, hogy a tudósközösség mikor és miért választ magának történeti, mikor és miért jelen-centrikus szemléletet. Nagyon fontos újra leszögeznem: tudósközösség alatt a dolgozatban nem a politológusok teljes társadalmát értem, hanem a fogalmat egy szúkebb szeletre, azokra alkalmazom, akik nem tartják maguktól távolinak a politikatudomány ideológiai felhasználását. A tanulmányban Thomas Kuhn megközelítését követtem, aki a tudományban jelen lévőnek tételezi ezt az ideológiai orientációt.

Arra jutottam, hogy az elmúlt hatvan évben Nyugat-Európában ciklikusan váltakoznak az ún. történelmi és az ún. történelem nélküli korszakok, s a politikatudósok hol a történelmet használják fel a jelennel, hol a jelent a történelemmel szemben. Az 1990-es kelet-közép-európai átalakulások egybeesnek a politikatudományon belüli jelen-centrikus fordulattal, s ez a paradigma egészen az 1990-es évek végéig, a 2000-es évek elejéig egyeduralkodó. Utána azonban ismét nagyobb keletje lesz a történelmi szemléletnek és egyre több nyugat-európai politikatudós kezdi vizsgálni Kelet-Közép-Európa társadalmait történelmi szemüvegen keresztül.

Ilyenfajta módosulás jeleit Kelet-Közép-Európában, s azon belül Magyarországon nem tapasztalhatjuk. Ha nálunk növekedett is valamelyest a történelmi szemléletmódú megközelítések száma, a mai magyar politikáról a megközelítések nagy része alapjában ma is jelen-centrikus. Ebből a dolgozat végén mindössze egy óvatos következtetést szeretnék levonni: a magyar politikatudomány mintha nem követné kellő figyelemmel a nemzetközi paradigmák dinamikáját és ciklikusságát, ebből adódóan kevés kísérletet tesz a fentebb új historicistának vagy az új politikai fejlődésnek nevezett paradigmák integrálására. Ily módon az 1990-2017 közötti magyar politikai fejlődés leírásában és elemzésében továbbra sem megfelelő kiterjedtségben kamatoztatjuk a mai nyugat-európai politikatudomány új felfedezéseit. Sajnos, az e tanulmányban bemutatott tranzitológiai és konszolidológiai irodalom sem tud elég mélyre ásni az 1990-ben kialakuló magyar demokrácia átalakulásának és a Fidesz „megváltozásának” értelmezésében. Éppen e miatt is a mai helyzet jobb, alaposabb megértéséhez a történelmi szemlélet gazdagabb kamatoztatása ajánlható. 


\section{KÖZELKÉP - Tanulmányok}

\section{Irodalom}

Ágh, A. (1992): A pártok parlamentesedése Magyarországon (1989-1991). Politikatudományi Szemle, 1.125-140.

Ágh, A. (1993): A polarizáció éve. Magyarország Politikai Évkönyve. In: Kurtán, S. Sándor, P. - Vass, L. (szerk.): Demokrácia Kutatások Magyar Központja. 40-57.

Ágh, A. (1998): A korai konszolidáció éve. Magyarország Politikai Évkönyve. In: Kurtán, S. - Sándor, P. - Vass, L. (szerk.) Demokrácia Kutatások Magyar Központja, 16-33.

Ágh, A. (2001): A korai konszolidáció és az EU-alkalmazkodás Közép-Európában. Politikatudományi Szemle, 1-2, 25-44.

Aron, R. (2005): Demokrácia és totalitarizmus. L’Harmattan Kiadó - Szegedi Tudományegyetem Filozófia Tanszék.

Belohradsky, V. (1992): A kapitalizmus és a polgári erény. Budapest, Kalligram Kiadó.

Capoccia, G. - Ziblatt, D. (2010): The Historical Turn in Democratization Studies: A New Research Agenda for Europe and Beyond. Comparative Political Studies, August-September, 931-968.

Carbone, G. (2015): Democratisation as a State Building Mechanism: A Preliminary Discussion of an Understudied Relationship. Political Studies. February, 11-21.

Csizmadia, E. (2009): A konszenzus gondolata a 2008. évi kormánypolitikában. Gyurcsány Ferenc stratégiája a Megegyezés című programban. Magyarország Politikai Évkönyve. Demokrácia Kutatások Központja Alapítvány. 504-515.

Csizmadia, E. (2014): Miért „alaptalan” a magyar demokrácia? Budapest, Gondolat Kiadó.

Csizmadia, E. (2016): A tranzitológiának vége, felejtsük el? Az átmenet tervezett intézményeitôl a tervezetlen hibridizációig. Politikatudományi Szemle, 2.135-153.

Csizmadia, E. (2017): A magyar politikai fejlődés logikája. Összehasonlítható-e a jelen a múlttal, és ha igen, hogyan? Budapest, Gondolat Kiadó.

Csizmadia, E. (2018): Időszemlélet és politikatudomány. Váltógazdálkodási ciklusok a jelen-centrikus és a történelmi szemléletmód között. Metszetek, 2.94-130.

Debreczeni, J. (2006): Populizmus, fasizmus, nácizmus. Mozgó Világ, December.

Debreczeni, J. (2009): A parlamenti kormányzás megbénítása. Mozgó Világ, Október.

Enyedi, Zs. (1998): Pártrendszer és politikai konszolidáció. Politikatudományi Szemle, 3. 5-32.

Fukuyama, F. (1990): A történelem vége? Valóság, március, 16-31.

G. Márkus, Gy. (1997): A törésvonalak három családja a kelet-közép-európai pártrendszerekben - Magyarország példája. Politikatudományi Szemle, 1. 42-54. 


\section{KÖZELKÉP - Tanulmányok}

Greven, M. T. (1995): Demokratizáció és intézményépítés. Politikatudományi Szemle, 1. 9-20.

Gyurcsány, F. (2006): Kicsi a különbség a miniszterelnök és a magánember szövegei közt. Rádai Eszter interjúja. Mozgó Világ, December.

Gyurcsány, F. (2007): Az új szociáldemokrácia. Ringier Kiadó.

Hack, P. (2002): A kormányzati hatalom ellensúlyainak megroppanása. In: Kurtán, S. - Sándor, P. - Vass, L. (szerk.): Magyarország Politikai Évkönyve. 113-121.

Hajduk, A. - Tornai, I. (2007): Kisebbségi kormányzás Magyarországon és Európában. Demos Alapítvány.

Husz, D. (1997): Elit-játszmák: a poszt-kommunista elitek kialakulása. Játékelméleti elemzés. Politikatudományi Szemle, 3. 71-104.

Jenne, E. K. - Mudde, C. (2012): Hungary's Illiberal Turn. Can Outsiders Help? Journal of Democracy, July, 147-155.

Karácsony, G. (2005): A történelem fogságában. Generációk, életutak és politikai preferenciák. In: Angelusz, R. - Tardos, R. (szerk.): Törések, hálók, hidak. Választói magatartás és politikai tagolódás Magyarországon. Demokrácia Kutatások Magyar Központja Közhasznú Alapítvány. 161-206.

Kéri, L. - Petschnig, M. Z. (2003): Szélsőségek éve. Magyarország Politikai Évkönyve. Kurtán, S. - Sándor, P. - Vass, L. (szerk.): Demokrácia Kutatások Magyar Központja, 126-138.

Kitschelt, H. (1992): Political Regime Change: Structure and Process-Driven Explanations? The American Political Science Review, December, 1028-1034.

Kitschelt, H. et al. (1999): Post-Communist Party Systems: Competition, Representation, and Inter-Party Cooperation. New York: Cambridge.

Kopeczky, P. - Mudde, C. (2000): Mire tanít minket a kelet-európai irodalom a demokratizálódásról (és viszont)? Politikatudományi Szemle, 3-4. 49-74.

Körösényi, A. - Patkós, V. (2015): Liberális és illiberális populizmus: Berlusconi és Orbán politikai vezetése. Politikatudományi Szemle, 2. 29-56.

Körösényi, A. (2001):Parlamentáris vagy „elnöki” kormányzás? Az Orbán-kormány összehasonlító perspektívából. Századvég, tavasz, 3-38.

Körösényi, A. (2005): Vezér és demokrácia. Politikaelméleti tanulmányok. Budapest, L'Harmattan Kiadó.

Körösényi, A. (2007): A jobboldal elhúzódó válsága. Kommentár, 4. 97l'101.

Körösényi, A. (2015): A magyar politikai rendszer - negyedszázad után. Budapest, Osiris Kiadó - MTA TK PTI.

Krastev, I. (2007): The Strange Death of the Liberal Consensus. The Journal of Democracy, October, 56-63. 


\section{KÖZELKÉP - Tanulmányok}

Kristóf, L. (2015): A politikai elit. In: Körösényi A. (szerk.) A magyar politikai rendszer - negyedszázad után. Budapest, Osiris - MTA-TK, PTI. 59-54.

Kuhn, T. (1984): A tudományos forradalmak szerkezete. Budapest, Gondolat Kiadó.

Lipset, S. M. - Rokkan, S. (1967): Party Systems and Voter Alignments: Cross-National Perspectives. Free Press.

Lipset, S. M. (1959): Some Social Requisites of Democracy: Economic Development and Political Legitimacy. The American Political Science Review, March, 69-105.

Marquette, H. - Beswick, D. (2011): State Building, Security and Development: state Building as a New Development Paradigm? Third World Quarterly, 10. 17031714.

Mudde, C. (2011): Who's Afraid of the European Radical Right? Dissent Magazine, Fall.

Nikolenyi, Csaba (2004): Cabinet Stability in Post-Communist Central Europe. Party Politics, 2. 123-150.

Offe, C. (1994): A kelet-európai átmenetek intézményeinek tervezése. Politikatudományi Szemle, 3. 5-32.

Offe, C. (1996): Consolidation and the Cleavages of Ideology and Identity. Berlin. Manuscript.

Orbán, V. (2006): Vízválasztó, I-II-III. Magyar Nemzet, július 29, augusztus 5; szeptember 9.

Petrétei, J. (2009): Az alkotmányos demokrácia alapintézményei. Dialóg - Campus Kiadó.

Plasser, F. - Ulram, P. (1995): Demokratikus konszolidáció Kelet-Közép-Európában. Politikatudományi Szemle, 1., 21-42.

Plattner, M. (2010): Populism, Pluralism and Liberaldemocracy. The Jorunal of Democracy. January, 81-92.

Ránki, Gy. (1983): Mozgásterek, kényszerpályák. Válogatott tanulmányok. Magvető Kiadó.

Róbert, P. - Papp, Zs. (2012): Kritikus választás? Pártos elkötelezettség és szavazói viselkedés a 2010-es országgyúlési választáson. In: Boda, Zs. - Szabó, A. (szerk.): Trendek a magyar politikában, 2. A Fidesz és a többiek: pártok, mozgalmak, politikák. Budapest, Napvilág Kiadó, 41-64.

Roberts, A. (2006): What Kind of Democracy is Emerging in Eastern Europe? PostSoviet Affairs, 1. 37-64.

Róna, D. (2008): A törésvonal fogalma a politikatudományban. Magyarország. Politikatudományi Szemle, 4.121-144. 


\section{KÖZELKÉP - Tanulmányok}

Sárközy, T. (2002): A kormányzati intézményrendszer és a politikai stratégia. Magyarország Politikai Évkönyve. Demokrácia Kutatások Magyar Központja Alapítvány, 54-89.

Sartori, G. (1999): Demokrácia. Osiris Kiadó.

Schedler, A. (2001): Measuring Democratic Consolidation. Studies in Comparative International Development, Spring, 66-92.

Stumpf (2009): Kormányválságtól a válságkormányzásig : a szocialista-liberális koalíció felbomlása és a kisebbségi kormányzás kihívásai. Magyarország Politikai Évkönyve. Kurtán Sándor - Sándor Péter - Vass László szerk. Demokrácia Kutatások Magyar Központja, 473-490. 